
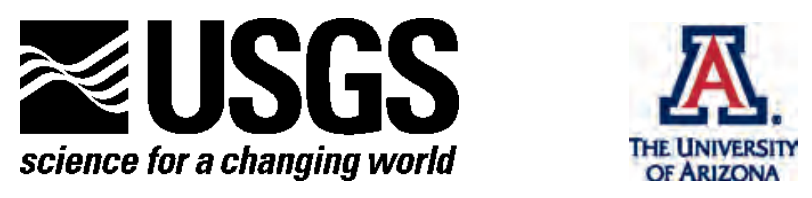

\title{
USA National Phenology Network Gridded Products Documentation
}

By Theresa M. Crimmins, R. Lee Marsh, Jeff R. Switzer, Michael A. Crimmins, Katharine L. Gerst, Alyssa H. Rosemartin, and Jake F. Weltzin

Open-File Report 2017-1003

U.S. Department of the Interior U.S. Geological Survey 


\section{U.S. Department of the Interior SALLY JEWELL, Secretary}

\section{U.S. Geological Survey William H. Werkheiser, Acting Director}

U.S. Geological Survey, Reston, Virginia: 2017

For more information on the USGS-the Federal source for science about the Earth, its natural and living resources, natural hazards, and the environment-visit https://www.usgs.gov/ or call 1-888-ASK-USGS (1-888-275-8747).

For an overview of USGS information products, including maps, imagery, and publications, visit https://www.usgs.gov/pubprod/.

Any use of trade, firm, or product names is for descriptive purposes only and does not imply endorsement by the U.S. Government.

Although this information product, for the most part, is in the public domain, it also may contain copyrighted materials as noted in the text. Permission to reproduce copyrighted items must be secured from the copyright owner.

Suggested citation:

Crimmins, T.M., Marsh, R.L., Switzer, J.R., Crimmins, M.A., Gerst, K.L., Rosemartin, A.H., and Weltzin, J.F., 2017, USA National Phenology Network gridded products documentation: U.S. Geological Survey Open-File Report 2017-1003, 27 p., https://doi.org/10.3133/ofr20171003.

ISSN 2331-1258 (online) 


\section{Acknowledgments}

Author contributions: Michael Crimmins, Katharine Gerst, Lee Marsh, Jeff Switzer, Alyssa Rosemartin, Jake Weltzin, and Theresa Crimmins conceptualized, designed, and developed the products; Theresa Crimmins and Lee Marsh wrote and assembled the first draft of the manuscript with sections contributed by Michael Crimmins, Katharine Gerst, and Alyssa Rosemartin; all authors reviewed the final draft. We offer special thanks to Toby Ault for his efforts creating the first generation of gridded Spring Index products, translating the original Spring Index Fortran code to Matlab, and developing supporting documentation. We also extend many thanks to Mark D. Schwartz for many years of collaborations and support in utilizing and applying the Spring Indices.

We appreciate the efforts of Mike Squires, Lizzie Wolkovich, Madeline Rubenstein, Raul Zurita-Milla, Tim Assal, and Wayne Thogmartin who provided detailed reviews of the gridded products and documentation. We are also grateful to the members of the USA-NPN Data Products Working Group, out of which the vision for these products arose.

Finally, we acknowledge the continued generous support of the U.S. Geological Survey and the University of Arizona for the establishment and maintenance of the USA National Phenology Network. 


\section{Contents}

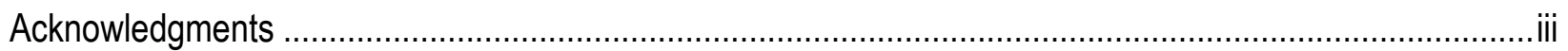

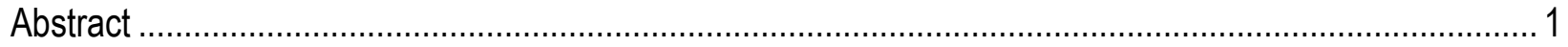

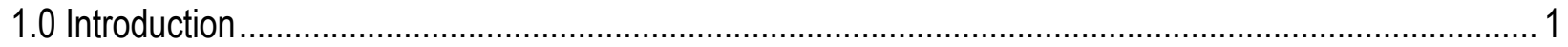

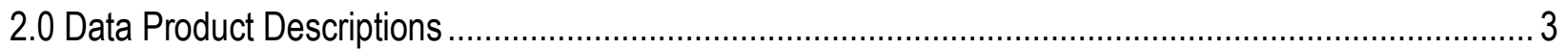

2.1 Accumulated Growing Degree Days ...................................................................................... 3

2.1.1 Daily Contemporary and Forecasted Temperature Accumulations ........................................... 3

2.1.2 Daily 30-Year Average Temperature Accumulations............................................................ 4

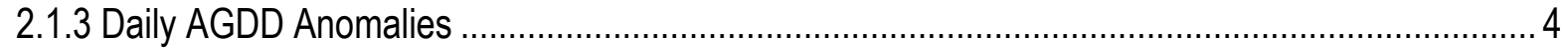

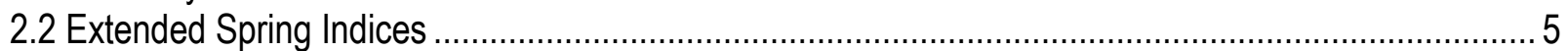

2.2.1 Historical Annual Spring Indices ..................................................................................... 6

2.2.2 Daily Contemporary and Short-term Forecasted Spring Indices................................................ 6

2.2.3 30-Year Average for Extended Spring Indices ................................................................... 7

2.2.4 Daily Spring Index Anomalies.......................................................................................

2.3 Temperature Inputs_-Daily Minimum and Maximum Temperatures ................................................ 8

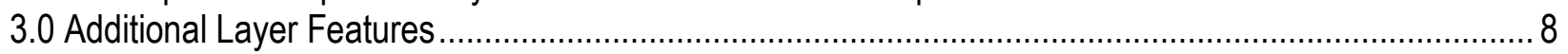

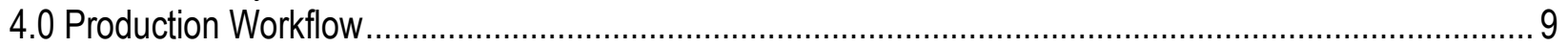

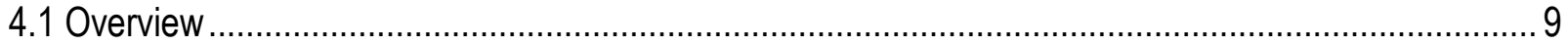

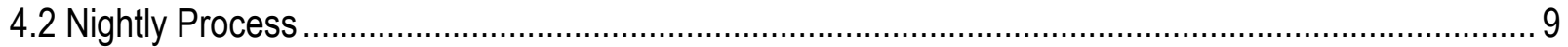

5.0 Web Services: Geoserver ..................................................................................................... 11

6.0 Changes to the Extended Spring Index Implementation ............................................................... 12

7.0 Uncertainty and Quality Control Checks on Gridded Products ....................................................... 12

7.1 Uncertainty Resulting from Underlying Climate Products.......................................................... 12

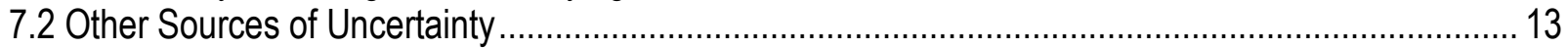

7.3 Planned Activities for Estimating Uncertainty in USA-NPN Gridded Products ................................ 14

7.3.1 Estimating Uncertainty in USA-NPN Real-Time Gridded Products............................................ 14

7.3.2 Estimating Uncertainty in USA-NPN Real-Time SI-x Products............................................... 15

7.3.3 Estimating Uncertainty in USA-NPN 1- to 6-Day Forecast AGDD Products............................... 15

7.3.4 Estimating Uncertainty in USA-NPN 1- to 6-Day Forecast SI-x Products .................................. 16

7.3.5 Estimating Uncertainty in USA-NPN Anomaly AGDD Products ............................................. 16

7.3.6 Estimating Uncertainty in USA-NPN Anomaly SI-x Products ................................................ 16

7.3.7 Estimating Uncertainty in USA-NPN Historical Data Products ............................................... 16

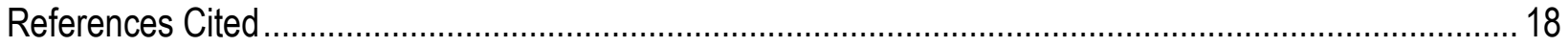

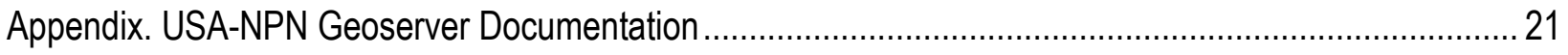




\section{Figures}

1. Diagram of nightly contemporary and forecasted climate data processing, illustrating how data from various sources are incorporated into the workflow.

2. Diagram of raster layers generated in nightly contemporary and forecasted climate data processing, showing each of the gridded products generated for the 10 days in the workflow shown in figure 1

\section{Tables}

1. Gridded phenology maps produced by the USA National Phenology Network.............................. 2

2. Planned activities for estimating uncertainty in USA-NPN gridded phenology products. 


\section{Abbreviations}

AGDD Accumulated Growing Degree Days

CRN Climate Reference Network

GMT Greenwich mean time

NCEP National Centers for Environmental Prediction

NDFD National Digital Forecast Database

NOAA National Oceanic and Atmospheric Administration

NWS National Weather Service

PRISM Parameter-elevation Relationships on Independent Slopes Model

RTMA Real-Time Mesoscale Analysis

SI-X Extended Spring Indices

URMA Unrestricted Mesoscale Analysis

USA-NPN USA National Phenology Network

WCS Web Coverage Service

WMS Web Mapping Service 


\title{
USA National Phenology Network Gridded Products Documentation
}

\author{
By Theresa M. Crimmins, ${ }^{1}$ R. Lee Marsh, ${ }^{1}$ Jeff R. Switzer, ${ }^{1}$ Michael A. Crimmins, ${ }^{2}$ Katharine L. Gerst, ${ }^{1}$ \\ Alyssa H. Rosemartin, ${ }^{1}$ and Jake F. Weltzin ${ }^{3}$
}

\begin{abstract}
The goals of the USA National Phenology Network (USA-NPN, www.usanpn.org) are to advance science, inform decisions, and communicate and connect with the public regarding phenology and species' responses to environmental variation and climate change. The USA-NPN seeks to facilitate informed ecosystem stewardship and management by providing phenological information freely and openly. One way the USA-NPN is endeavoring to accomplish these goals is by providing data and data products in a wide range of formats, including gridded real-time, short-term forecasted, and historical maps of phenological events, patterns and trends (Gerst and others, 2015). This document describes the suite of gridded phenologically relevant data products produced and provided by the USA National Phenology Network, which can be accessed at www.usanpn.org/data/phenology_maps and also through web services at geoserver.usanpn.org/geoserver/wms?request=GetCapabilities.
\end{abstract}

\subsection{Introduction}

The goals of the USA National Phenology Network (USA-NPN, www.usanpn.org/) are to advance science, inform decisions, and communicate and connect with the public regarding phenology and species' responses to environmental variation and climate change (USA-NPN National Coordinating Office, 2014). The USA-NPN seeks to facilitate informed ecosystem stewardship and management by providing phenological information freely and openly.

One way the USA-NPN is supporting science and society is by providing data and data products in a wide range of formats, including gridded maps of phenological events, patterns, and trends (Gerst and others, 2015). The first two suites of gridded products to be released by the USA-NPN include historical, real-time, and short-term forecasted predictions of accumulated temperature (Accumulated Growing Degree Days) and the Extended Spring Indices (table 1).

Accumulated Growing Degree Days and the Extended Spring Indices are both representations of accumulated temperature. As accumulated winter and spring heat drives many spring season phenological events in much of the country, these products can be used to better understand patterns in the current and historical timing of these events across the landscape. The

\footnotetext{
${ }^{1}$ University of Arizona, School of Natural Resources and the Environment.

${ }^{2}$ University of Arizona, Department of Soil, Water, and Environmental Science.

${ }^{3}$ U.S. Geological Survey.
} 
Table 1. Gridded phenology maps produced by the USA National Phenology Network.

\begin{tabular}{|c|c|c|c|c|c|}
\hline Product suite & Data product & Source data & $\begin{array}{l}\text { Spatial } \\
\text { resolution }\end{array}$ & $\begin{array}{l}\text { Temporal } \\
\text { resolution }\end{array}$ & Temporal extent \\
\hline \multirow[t]{3}{*}{$\begin{array}{l}\text { Accumulated } \\
\text { Growing } \\
\text { Degree } \\
\text { Days }\end{array}$} & $\begin{array}{l}\text { Daily Contemporary } \\
\text { and Forecasted } \\
\text { Temperature } \\
\text { Accumulations }\end{array}$ & $\begin{array}{l}\text { RTMA, } \\
\text { URMA, }^{2} \\
\text { NDFD }^{3}\end{array}$ & 2.5 kilometer & Daily & $\begin{array}{l}\text { Beginning January } \\
1,2016 \text { : January } \\
1 \text { through current } \\
\text { day plus } 1 \text { - to } 6- \\
\text { day forecasts }\end{array}$ \\
\hline & $\begin{array}{l}\text { Daily 30-Year } \\
\text { Average } \\
\text { Temperature } \\
\text { Accumulations }\end{array}$ & $\mathrm{PRISM}^{4}$ & $\begin{array}{l}2.5 \text { kilometer } \\
\text { (resampled } \\
\text { from } 4 \\
\text { kilometer) }\end{array}$ & Daily & $\begin{array}{l}1-365 \text { (day of } \\
\text { year), calculated } \\
\text { over } 1981-2010\end{array}$ \\
\hline & Daily Anomalies & $\begin{array}{l}\text { RTMA, } \\
\text { URMA, }^{2} \\
\text { NDFD }^{3} \\
\text { PRISM }^{4}\end{array}$ & 2.5 kilometer & Daily & $\begin{array}{l}\text { Beginning January } \\
1,2016 \text { : January } \\
1 \text { through current } \\
\text { day plus } 1 \text { - to 6- } \\
\text { day forecasts }\end{array}$ \\
\hline \multirow{4}{*}{$\begin{array}{l}\text { Extended } \\
\text { Spring } \\
\text { Indices }\end{array}$} & $\begin{array}{l}\text { Historical Annual } \\
\text { Spring Indices }\end{array}$ & $\mathrm{PRISM}^{4}$ & 4 kilometer & Yearly & 1981-2015 \\
\hline & $\begin{array}{l}\text { Daily Contemporary } \\
\text { and Short-term } \\
\text { Forecasted Spring } \\
\text { Indices }\end{array}$ & $\begin{array}{l}\text { RTMA, } \\
\text { URMA, }^{2} \\
\text { NDFD }^{3}\end{array}$ & 2.5 kilometer & Daily & $\begin{array}{l}\text { Beginning January } \\
1,2016 \text { : January } \\
1 \text { through current } \\
\text { day plus } 1 \text { - to 6- } \\
\text { day forecasts }\end{array}$ \\
\hline & $\begin{array}{l}\text { 30-Year Average for } \\
\text { Extended Spring } \\
\text { Indices }\end{array}$ & PRISM $^{4}$ & $\begin{array}{l}2.5 \text { kilometer } \\
\text { (resampled } \\
\text { from } 4 \\
\text { kilometer) }\end{array}$ & $\begin{array}{l}\text { Not } \\
\quad \text { applicable }\end{array}$ & $1981-2010$ average \\
\hline & $\begin{array}{l}\text { Daily Spring Index } \\
\text { Anomalies }\end{array}$ & $\begin{array}{l}\text { RTMA, } \\
\text { URMA, }^{2} \\
\text { NDFD, }^{3} \\
\text { PRISM }^{4}\end{array}$ & 2.5 kilometer & Daily & $\begin{array}{l}\text { Beginning January } \\
\text { 1, 2016: January } \\
1 \text { through current } \\
\text { day plus } 1 \text { - to } 6- \\
\text { day forecasts }\end{array}$ \\
\hline $\begin{array}{l}\text { Temperature } \\
\text { Inputs }^{5}\end{array}$ & $\begin{array}{l}\text { Daily Temperature } \\
\text { Minimum and } \\
\text { Maximums }\end{array}$ & $\begin{array}{l}\text { RTMA, }^{1} \\
\text { URMA, }^{2} \\
\text { NDFD }^{3}\end{array}$ & 2.5 kilometer & Daily & $\begin{array}{l}\text { Beginning January } \\
\text { 1, 2016: January } \\
1 \text { through current } \\
\text { day plus } 1 \text { - to 6- } \\
\text { day forecasts }\end{array}$ \\
\hline
\end{tabular}

${ }^{1}$ National Oceanic and Atmospheric Administration (NOAA) National Centers for Environmental Prediction (NCEP) Real-Time Mesoscale Analysis products (www.nco.ncep.noaa.gov/pmb/products/rtma/).

${ }^{2}$ NOAA NCEP Unrestricted Mesoscale Analysis products (www.nco.ncep.noaa.gov/pmb/products/rtma/\#URMA).

${ }^{3}$ NOAA National Weather Service National Digital Forecast Database (www.nws.noaa.gov/ndfd/).

${ }^{4}$ Parameter-elevation Relationships on Independent Slopes Model (www.prism.oregonstate.edu/).

${ }^{5}$ Temperature data layers serve as inputs for USA National Phenology Network (USA-NPN) Accumulated Growing Degree Days and Extended Spring Indices products, and are also made available via the USA-NPN Geoserver. 
Extended Spring Indices yield a day of year that the criteria for the indices were met, and the Accumulated Growing Degree Days products are a continuously growing total of heat units within each pixel. As such, the two metrics offer complementary information and are best suited for different applications.

Here we introduce the two suites of products, followed by descriptions of each available layer, including information on the extent of data available, how to access layers, and the workflow and underlying climate data used to generate the layers. These products can be accessed at www.usanpn.org/data/phenology_maps and also through Web services cat geoserver.usanpn.org/geoserver/wms? request=GetCapabilities.

These two suites of gridded products are the first of many that will be created and maintained by the USA-NPN (Gerst and others, 2015). We anticipate following the workflow described for creating these products to produce historical and current maps of spring, summer, and fall phenophases (observable life cycle stages that can be defined by a start and end point) for a wide array of species or taxonomic groups for the contiguous United States and, eventually, Alaska and Hawaii. As additional suites of gridded products are added to the USA-NPN's list of data products, they will be described at www.usanpn.org/data/new_data_products and will be added to this report via periodic updates.

\subsection{Data Product Descriptions}

\subsection{Accumulated Growing Degree Days}

Heat accumulation is commonly used as a way of predicting the timing of phenological transitions in plants and animals, including when plants exhibit leaf out, flowering, or fruit ripening, or when insects emerge from dormancy (Cross and Zuber, 1972; McMaster and Wilhelm, 1997). This is typically expressed as accumulated heat units, either Growing Degree Hours or Growing Degree Days. Growing degree day thresholds have been established for many species, and are commonly used in agriculture, horticulture, and pest management to schedule activities such as harvesting, pesticide treatment, and flower collection.

The USA-NPN is currently generating Accumulated Growing Degree Days (AGDD) products using a January 1, 2016, start date and two base temperatures, 32 degrees Fahrenheit $\left({ }^{\circ} \mathrm{F}\right)$ and $50{ }^{\circ} \mathrm{F}$. More information is available at www.usanpn.org/data/agdd_maps.

\subsubsection{Daily Contemporary and Forecasted Temperature Accumulations}

Underlying climate data: National Oceanic and Atmospheric Administration (NOAA) National Centers for Environmental Prediction (NCEP) Real-Time Mesoscale Analysis (RTMA) products, NOAA NCEP Unrestricted Mesoscale Analysis (URMA) products, and NOAA National Weather Service (NWS) National Digital Forecast Database (NDFD)

Spatial resolution: 2.5 kilometer $(\mathrm{km})$

Temporal resolution: Daily

Temporal extent: Beginning January 1, 2016, January 1 through current day plus 1 - to 6-day forecasts

Units: Accumulated growing degree days (AGDD) based on January 1 start date and base temperature of $32^{\circ} \mathrm{F}$ or $50{ }^{\circ} \mathrm{F}$ 
Additional features available: State boundaries

Description: These layers represent the amount of heat accumulated in each pixel. There is one layer for each day of the year up through the current day, plus 6 days into the future. Grid cell values begin at 0 and increase as heat units begin to accumulate. These grids are updated on a nightly process.

By adjusting the day of year that is viewed, the user can explore the amount of heat accumulated at any location on that day. The user may also explore the growing degree days anticipated to accumulate in the next 1 to 6 days, based on short-term temperature forecast products (NDFD).

Each night, the layers are regenerated for the previous 3 days, the current day, and the next 6 days. This allows more stable data and better forecasts to be incorporated into each day's representation of the model. Because the short-term forecasts are adjusted daily, pixel values may vary from one day to the next. Please see the workflow section for more details.

\subsubsection{Daily 30-Year Average Temperature Accumulations}

Underlying climate data: Parameter-elevation Relationships on Independent Slopes Model (PRISM)

Spatial resolution: $2.5 \mathrm{~km}$ (resampled from $4 \mathrm{~km}$ )

Temporal resolution: Daily

Temporal extent: 1-365 (day of year; DOY)

Units: Accumulated growing degree days based on January 1 start date and base temperature of $32^{\circ} \mathrm{F}$ or $50^{\circ} \mathrm{F}$

Additional features available: State boundaries

Description: These layers show the 1981-2010 average of AGDD for each day of the year, for each base temperature. These long-term averages were created by averaging the accumulated growing degree day grids for the same day of the year over the span 1981-2010 for each base temperature. These averaged grids for a particular day of year (DOY) are calculated as follows:

$((1981$ AGDD grid DOY $)+(1982$ AGDD grid DOY $)+\ldots+(2010$ AGDD grid DOY $)) / 30$

for example, for January 1 the equation would be as follows:

$$
((\text { January 1, 1981, AGDD grid) }+ \text { (January 1, 1982, AGDD grid })+\ldots+(\text { January 1, 2010, }
$$
AGDD grid)) / 30

These annual grids were generated using historical PRISM data which were resampled using bilinear interpolation from the native $4-\mathrm{km}$ resolution to $2.5-\mathrm{km}$ resolution to match the resolution of the other gridded products in this suite. These layers will be recalculated each decade, incorporating the previous decade's data (for example, the layers will be recalculated in 2021 using data from 1991-2020). These grids are summed on day of year; as such, in leap years, December 31 is excluded.

\subsubsection{Daily AGDD Anomalies}

Underlying climate data: NOAA NCEP RTMA products, NOAA NCEP URMA products, NOAA NWS NDFD, and PRISM 
Spatial resolution: $2.5 \mathrm{~km}$

Temporal resolution: Daily

Temporal extent: Beginning January 1, 2016, January 1 through current day plus 1- to 6-day forecasts

Units: Accumulated Growing Degree Days based on January 1 start date and base temperature of $32^{\circ} \mathrm{F}$ or $50^{\circ} \mathrm{F}$

Additional features available: State boundaries

Description: These layers show the difference between the Daily Contemporary and Forecasted Temperature Accumulations and the 30-Year Average Temperature Accumulations, showing how much warmer or cooler the cumulative temperature is compared to long-term average cumulative temperature conditions, on any day of the year. These values are calculated as follows, for a particular DOY:

$$
\text { (Selected day's values) - (30-year average values) }
$$

such that negative values represent locations that have not yet reached the average heat accumulation this year for that day and positive values represent locations that have exceeded the average number of heat units accumulated this year for that day.

There is a layer for each day of the year, including the current day and 1 through 6 days into the future based on the NDFD forecast layers. These layers are regenerated following the same schedule as the Daily Contemporary and Forecasted Temperature Accumulations (section 2.1.1.), incorporating improvements to the data as described in the above section.

\subsection{Extended Spring Indices}

The Extended Spring Indices are mathematical models that predict the "start of spring" (timing of first leaf or first bloom) at a particular location (Schwartz, 1997; Schwartz, Ahas, and Aasa, 2006; Schwartz, Ault, and Betancourt, 2013). These models were constructed using historical observations of the timing of first leaf and first bloom in a cloned lilac cultivar (Syringa X chinensis 'Red Rothomagensis') and two cloned honeysuckle cultivars (Lonicera tatarica L. 'Arnold Red' and Lonicera korolkowii Stapf, also known as 'Zabelii'), which were selected based on the availability of historical observations from across a wide geographic area (Schwartz, 1997). Primary inputs to the model are temperature and weather events, beginning January 1 of each year (Ault, Zurita-Milla, and Schwartz, 2015). The model outputs are first leaf and first bloom date for a given location.

As the Extended Spring Index models are based on individual models for each of three calibration species, model output is available for each of these species individually, or as an average of the three species. The USA-NPN's implementation of the Extended Spring Indices to generate the products described below has been modified from previously published versions of the model; these changes are documented in section 6.0. The original Spring Indices (Schwartz, 1997) included a chilling requirement. In a more recent version of the model (Schwartz, Ault, and Betancourt, 2013), referred to as the Extended Spring Indices, the chilling requirement was excluded, allowing the index to be extended across the entire United States (Ault, Schwartz, and others, 2015). All the data products described here are based on the Extended Spring Indices. The term "Spring Indices" (and abbreviation SI-x) is used in this document as shorthand for the Extended Spring Indices. More information is available at www.usanpn.org/data/spring_indices. 
By convention, the Extended Spring Index models do not incorporate new data into the model after day 240.

\subsubsection{Historical Annual Spring Indices}

\section{Underlying climate data: PRISM}

Spatial resolution: $4 \mathrm{~km}$

Temporal resolution: Yearly

Temporal extent: 1981-2015

Units: Day of year

Additional features available: State boundaries (composite maps only)

Description: These layers are annual representations of the days of year that the requirements for the first leaf or first bloom Spring Indices were met, from 1981 to 2015 (one layer per year), calculated using PRISM minimum and maximum temperature data (Tmin and Tmax, respectively). These annual layers are calculated as PRISM Tmin and Tmax values reach a "stable" state. (PRISM data typically transition from "preliminary" to "stable" on a 6-month cycle; www.prism.oregonstate.edu/calendar/.) See section 4.0 for more details.

For each year, both first leaf and first bloom layers are available for each of the three species threshold models as well as for the first leaf and first bloom Spring Indices, which are the average of the three first leaf or first bloom species threshold models.

\subsubsection{Daily Contemporary and Short-term Forecasted Spring Indices}

Underlying climate data: NOAA NCEP RTMA products, NOAA NCEP URMA products, and NOAA NWS NDFD

Spatial resolution: $2.5 \mathrm{~km}$

Temporal resolution: Daily

Temporal extent: Beginning January 1, 2016, January 1 through current day plus 1 - to 6-day forecasts

Units: Day of year

Additional features available: State boundaries (composite maps only)

Description: These layers represent the progression of the first leaf and first bloom Spring Indices in the current year. There is one layer for each day of the year up through the current day, plus 6 days into future. These grids are updated on a nightly process. A cell is not shaded with the day of year that the Spring Index requirements are met until the requirements for each of the three species threshold models have been met.

By adjusting the day of year that is viewed, the user can explore the locations where the Spring Index requirements have been reached, as well as pixels where the Spring Index requirements are anticipated to be met in the coming 6 days, based on short-term temperature forecast products (NDFD).

Each night, the layers are regenerated for the previous 3 days, the current day, and the next 6 days. This allows more stable data and better forecasts to be incorporated into each day's 
representation of the model. Because the short-term forecasts are adjusted daily, the pixels anticipated to reach the requirements for the Indices may vary from one day to the next. Please see the workflow section for more details.

\subsubsection{0-Year Average for Extended Spring Indices}

Underlying climate data: PRISM

Spatial resolution: $2.5 \mathrm{~km}$ (resampled from $4 \mathrm{~km}$ )

Temporal resolution: Not applicable

Temporal extent: 1981-2010 average

Units: Day of year

Additional features available: State boundaries

Description: These two layers show the 30-year average day of year for the first leaf or first bloom Spring Indices. These layers are not available for individual species threshold models, only for the Spring Indices (the average of the three species).

These long-term averages were created by averaging the annual Spring Index layers generated for each year in 1981-2010, as described above for Historical Annual Spring Indices, where each year's grid depicts the day of year the Index requirements were reached in that year. These long-term average grids are calculated as follows:

$$
((1981 \text { SI-x grid })+(1982 \text { SI-x grid })+\ldots+(2010 \text { SI-x grid })) / 30
$$

These annual grids were generated using historical PRISM data which were resampled using bilinear interpolation from the native $4-\mathrm{km}$ resolution to $2.5-\mathrm{km}$ resolution to match the resolution of the other gridded products in this suite. These layers will be recalculated each decade, incorporating the previous decade's data (for example, the layers will be recalculated in 2021 using data from 1991-2020).

\subsubsection{Daily Spring Index Anomalies}

Underlying climate data: NOAA NCEP RTMA products, NOAA NCEP URMA products, NOAA NWS NDFD, and PRISM

Spatial resolution: $2.5 \mathrm{~km}$

Temporal resolution: Daily

Temporal extent: Beginning January 1, 2016, January 1 through current day plus 1-to 6-day forecasts

Units: Days

Additional features available: State boundaries

Description: These layers show the difference, in days, between the Daily Contemporary and Short-term Forecasted Spring Indices and the 30-Year Average for Spring Indices. The layers show how advanced or lagged the day of year of the first leaf and first bloom Spring Indices are, for the current year in a given location, compared to long-term averages. These values are calculated as follows: 


$$
\text { (Current year's values) - (30-year average values) }
$$

such that negative values represent locations that have reached or are anticipated to reach the SI-x requirements earlier than average, and positive values represent locations that have reached or are anticipated to reach the SI-x requirements later than average.

There is a layer for each day of the year, including the present day and up through 6 days into the future based on NDFD forecast data. These layers are regenerated following the same schedule as the Daily Contemporary Data, incorporating improvements to the data as described above in the Contemporary Data section.

These layers are not available for individual species threshold models, only the Spring Indices (the average of the three species threshold models).

\subsection{Temperature Inputs-Daily Minimum and Maximum Temperatures}

The daily minimum and maximum temperature data layers used to produce the Accumulated Growing Degree Days and Extended Spring Indices products described above are also made available for access and analysis.

Underlying climate data: NOAA NCEP RTMA products, NOAA NCEP URMA products, and NOAA NWS NDFD

Spatial resolution: $2.5 \mathrm{~km}$

Temporal resolution: Daily

Temporal extent: Beginning January 1, 2016, January 1 through current day plus 1- to 6-day forecasts

Units: Degrees Fahrenheit

Description: These layers represent daily temperature minimums and maximums as expressed in degrees Fahrenheit in each cell. There are two grids for each calendar day — one for minimum temperatures, and one for maximum temperatures.

By adjusting the day of year that is viewed, the user can explore minimum and maximum temperatures reported for that day. The user may also explore the anticipated minimum and maximum temperatures for the coming 1 to 6 days, based on short-term temperature forecast products (NDFD).

Each night, the layers are regenerated for the previous 7 days, the current day, and the next 6 days. This allows more stable data and better forecasts to be incorporated into each day's representation of the model. Because the short-term forecasts are adjusted daily, pixels values may vary from one day to the next. Please see the workflow section for more details.

In their native format, the NDFD data are at a daily resolution. RTMA and URMA data are at an hourly resolution. Hence, the daily values are derived from the hourly temperatures. The RTMA and URMA data are available in Greenwich mean time (GMT). To make RTMA and URMA data comparable to PRISM data, they are shifted to GMT -12 .

\subsection{Additional Layer Features}

Some data layers have been configured to allow additional information to be displayed along with the base raster data. These features are described below. Using an additional feature 
requires modifying the request for data. Feature availability is noted in the layer descriptions above.

Political State boundaries (2014) of the contiguous United States (U.S. Census Bureau, 2015) can be added to many of the gridded layers described above.

\subsection{Production Workflow}

\subsection{Overview}

Most of the work required to maintain these products is handled through a series of Python scripts custom-developed specifically for this purpose. These scripts are configured to automatically run at various time intervals, as to handle each of the products as appropriate. The raster data generated by these scripts are populated in a PostGreSQL database, enabled with PostGIS support. Geoserver, an Open Geospatial Consortium (OGC)-compliant Web app, is then used to access the database and presents that data as a series of layers, ready for retrieval by end users via the Internet.

\subsection{Nightly Process}

Time: Between 2200 and 0200 GMT -7

Description: The nightly process is used to regularly generate and regenerate recent, current, and future layers with newer and improved data. Specifically, the following climate data and layers are updated in the following process (figs. 1, 2):

1. Data retrieval

- NDFD forecast data (daily Tmin and Tmax) are retrieved for the forthcoming 6 days.

- NCEP RTMA data (hourly temperatures) are retrieved for the past 24 hours.

- NCEP URMA data (hourly temperatures) are retrieved for the past 24 hours.

- PRISM data that have transitioned into a "stable" state in the last 24 hours are retrieved.

2. Daily Tmin and Tmax are generated for the previous 7 days ( $t-1$ through $t-7)$ from the retrieved URMA and RTMA hourly data. In this step, URMA data are always given preference and RTMA data are only used for hours where URMA data are not yet available.

3. AGDD and SI-x layers

- AGDD

- Accumulated growing degree days (AGDD) layers are populated from 3 days in the past $(t-3)$ to 6 days into the future $(t+6)$ using the Tmin and Tmax data from the previous steps. Preference of backing climate data in this step is to use URMA when available, then falling back to RTMA, and finally NDFD.

- Accumulated growing degree day anomaly layers are created for each AGDD layer populated in the previous step.

- SI-X

- Spring Index layers are populated from 3 days in the past $(\mathrm{t}-3)$ to 6 days into the future $(\mathrm{t}+6)$ using the Tmin and Tmax data from the previous steps. Preference of 
backing climate data in this step is to use URMA when available, then falling back to RTMA, and finally NDFD.

- Spring Index anomaly layers are created for the species-averaged Spring Index layers populated in the previous step.

- Previous year Spring Index layers are populated using newly retrieved, stable PRISM data.

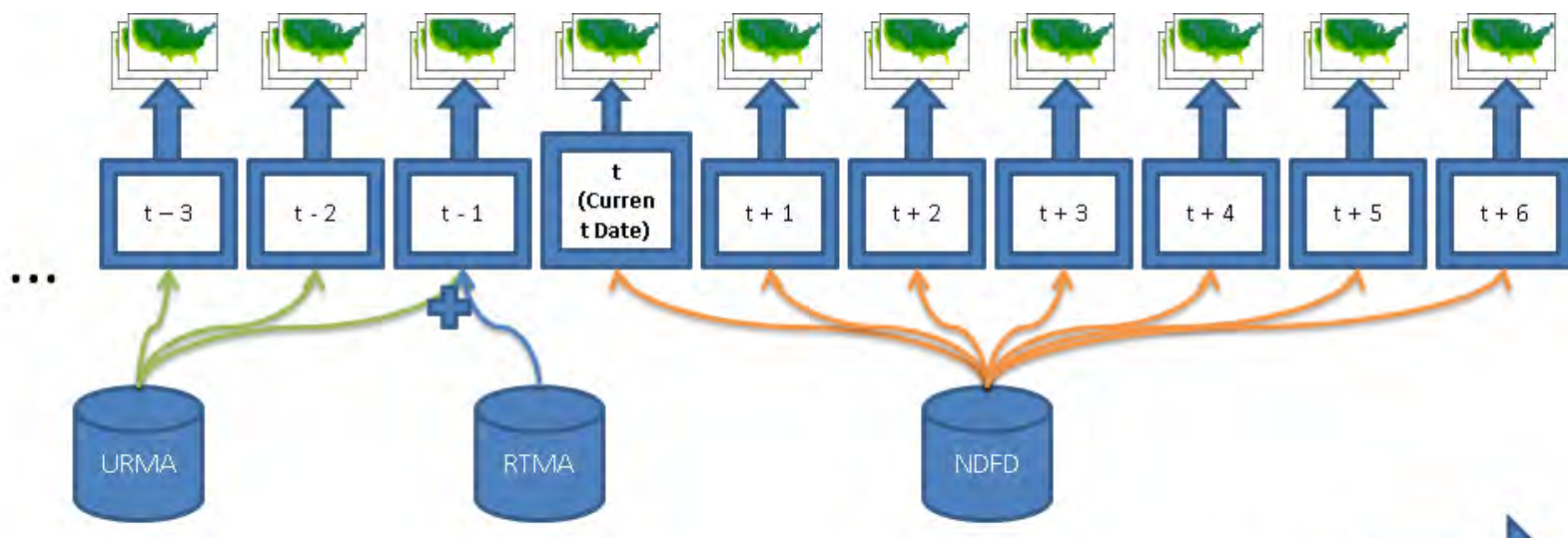

24 Hours Later

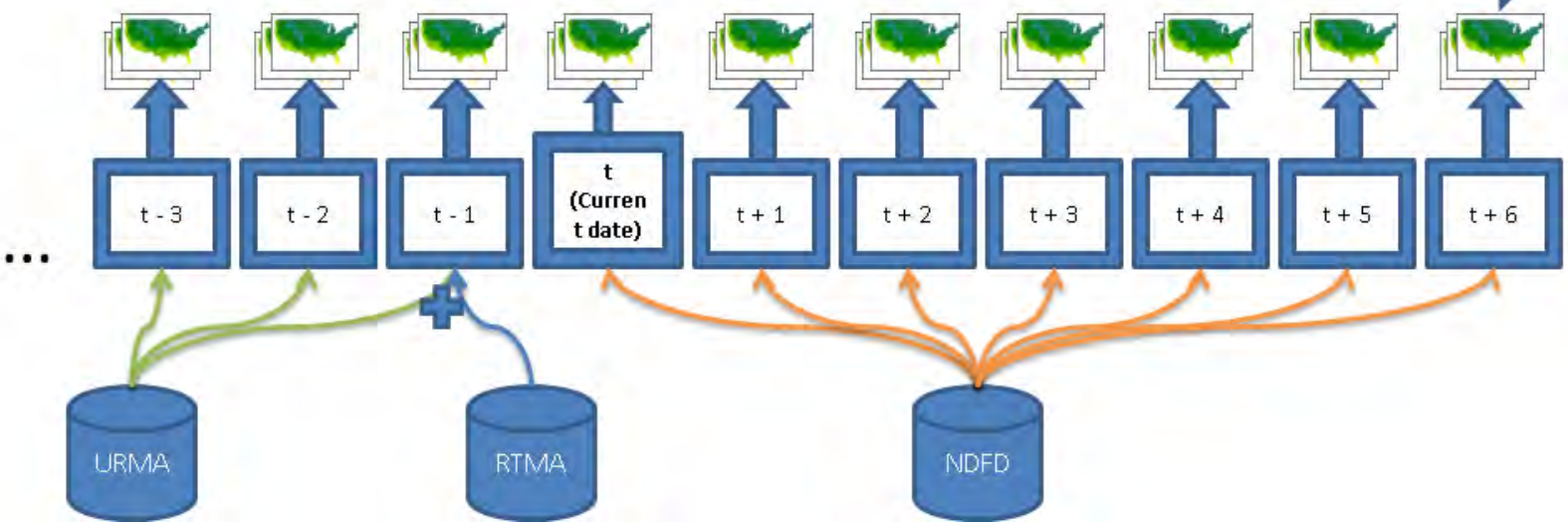

Figure 1. Diagram of nightly contemporary and forecasted climate data processing, illustrating how data from various sources are incorporated into the workflow. The top panel depicts the workflow with the current date $(t)$ set at January 15; the bottom panel depicts the following day. Every night, each AGDD and SI-x base layer (as depicted in figure 2 ) is regenerated for 10 days ( $t-3$ through $t+6)$. Unrestricted Mesoscale Analysis (URMA) products are used to generate data for the layers for the previous 3 days. Yesterday's layer is generated using URMA and Real-Time Mesoscale Analysis (RTMA) product data. National Digital Forecast Database (NDFD) data are used to create layers for the current date and each of the next 6 days. Once a day has reached $t-3$, its layers have been written twice using URMA data, and are considered finalized. 


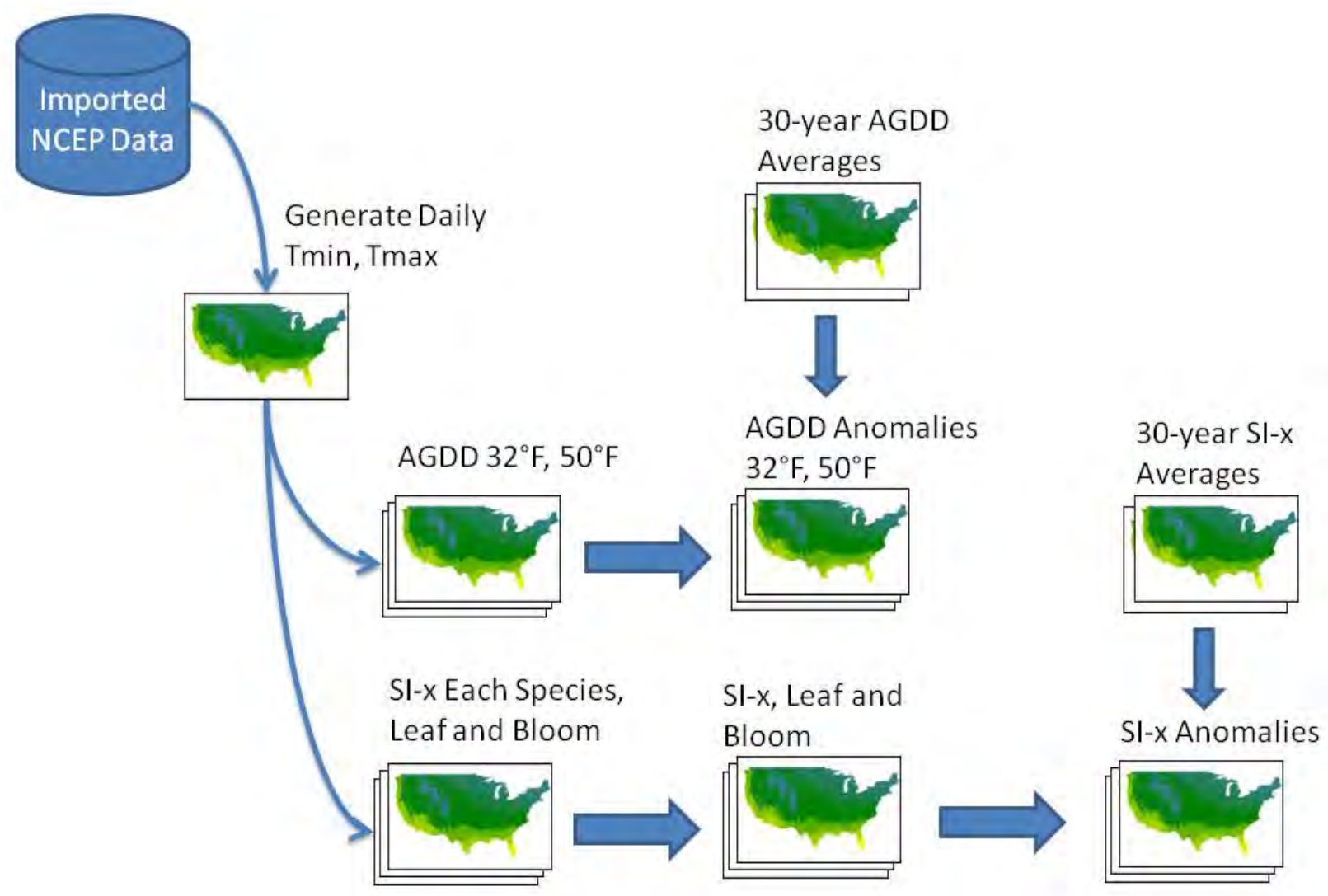

Figure 2. Diagram of raster layers generated in nightly contemporary and forecasted climate data processing, showing each of the gridded products generated for the 10 days in the workflow shown in figure 1. First, daily minimum (Tmin) and maximum (Tmax) temperature grids are created from the three National Oceanic and Atmospheric Administration (NOAA) data products (Unrestricted Mesoscale Analysis, Real-Time Mesoscale Analysis, and National Digital Forecast Database). Those products are leveraged to create Accumulated Growing Degree Days (AGDD) layers and Extended Spring Indices (SI-x) layers for each of the calibration species, shown in the two horizontal pathways in this diagram. The daily anomaly maps are generated from the difference between the contemporary and the 30-year average AGDD and composite SI-x raster layers. For the Spring Indices, SI-x raster layers for each calibration species are combined to generate the composite SI-x layers, and then are used to generate daily anomaly maps for the composite spring indices.

\subsection{Web Services: Geoserver}

All aforementioned data products are exposed to the Web via a Geoserver implementation of the OGC-compliant Web Mapping Services (WMS) and Web Coverage Services (WCS). This makes the data available over the Internet and requires no user authentication or authorization. Geoserver allows for the data to be presented dynamically in a variety of formats, projections, and dimensions as specified by the end user. Geoserver also selfreports on the various data and formats it has available. Please refer to the Geoserver 
Documentation (appendix A) for complete details about how to interface with the WMS and WCS.

\subsection{Changes to the Extended Spring Index Implementation}

Historically, the Spring Indices were calculated via routines implemented in Fortran (Schwartz, 1992) and Matlab (Ault, Zurita-Milla, and Schwartz, 2015). The USA-NPN's implementation uses Python scripts (github.com/usa-npn/gridded_models). Some small changes were made to the USA-NPN's Python implementation of the Extended Spring Index model (Ault, Schwartz, and others, 2015). Hence, using the same input data on these different products might produce small variations in the results.

The specific change in the current implementation involves sub-zero data processing. In previous implementations of the Spring Index, if a day's maximum temperature did not exceed the base temperature, then all processing was skipped for that day. However, in a C\# implementation of the model (Allstadt and others, 2015), it was discovered that this approach causes the code to accumulate synoptic events over nonconsecutive days, when in fact, by definition, a synoptic event must occur over the course of consecutive days. The USA-NPN implementation, used in the creation of the SI-X products described above, reflects this logic.

\subsection{Uncertainty and Quality Control Checks on Gridded Products}

As with all gridded data products, the USA-NPN gridded products inherently contain uncertainty or error arising from multiple sources, including error propagated forward from underlying climate data and from models used in the calculations. We aim to identify and report, where possible, measures of uncertainty, to support the use of these data products in decision making.

\subsection{Uncertainty Resulting from Underlying Climate Products}

Gridded temperature data products, which serve as the basis for derived products such as the Accumulated Growing Degree Days and Extended Spring Indices, inherently possess uncertainty, arising through interpolation (that is, mapping point-based station observations to continuous grids) techniques. Even though the gridded climate data products used in the creation of USA-NPN gridded products make use of complex and widely accepted interpolation and data assimilation techniques, these modeled estimates of the spatial climate suffer from a measure of uncertainty. Several factors make estimating temperature across space difficult, including elevation, coastal effects, slope and aspect, riparian zones, and land use and (or) landcover (Daly, 2006; Daly and others, 2008). The error associated with the temperature model outputs is not uniform across space or time (Daly, 2006; Pielke and others, 2002); temperatures may be less reliable near urban areas due to heat island effects, in coastal areas, in topographically complex regions, and near riparian areas. Measurement error at input stations is also often difficult to detect and can be incorporated into gridded climate products leading to propagation of these errors over space. The effects of factors such as elevation, terrain-induced climate transitions, cold air drainage and inversions, and coastal effects are greatest at resolutions less than $10 \mathrm{~km}$ (Daly, 2006). Most gridded climate products are made available without estimates of uncertainty (Bishop and Beier, 2013; Behnke and others, 2016).

The USA-NPN selected PRISM as the underlying data for historical data products because these products are constructed using a weighted local regression technique that accounts 
for physiographic factors affecting spatial climate variations and has a historical record extending back in time beyond 30 years (back to 1981 for daily temperature grids). The PRISM data resources are among the most renowned and widely applied gridded climate data products (Daly and others, 1994, 2002, 2008; Bishop and Beier, 2013; Oswald and Dupigny-Giroux, 2015). However, PRISM does not make estimates of error for their products publicly available. The USA-NPN selected RTMA, URMA, and NDFD climate products as the underlying products for the creation of current-year phenology gridded products for several reasons. The use of the relatively new Real-Time Mesoscale Analysis (RTMA; de Pondeca and others, 2011) and Unrestricted Mesoscale Analysis (URMA) datasets, a suite of gridded meteorological variables available on an hourly basis, offers the development of daily temperature-based products such as Accumulated Growing Degree Days and Extended Spring Indices that can be produced with minimal latency. Furthermore, the RTMA grid is common to the National Digital Forecast Database (NDFD; Glahn and Ruth, 2003), the seamless and common forecast grid of sensible weather elements such as surface temperature produced by the NOAA NWS. The combination of RTMA and URMA data and NDFD forecast temperature grids allows for the creation of phenologically relevant gridded products, including forecasted Accumulated Growing Degree Days up to a week in advance.

The NDFD is an incredible resource; however, it is subject to the inherent errors and uncertainty associated with meteorological forecasting and should accordingly be used with caution (Abrams, 2004; Slingo and Palmer, 2011). Weather prediction has improved dramatically over the past several decades (Slingo and Palmer, 2011) and the NDFD system capitalizes on the expertise of local forecast offices as well as the latest generation of meteorological models at their disposal (Glahn and Ruth, 2003). NDFD forecast performance is regularly evaluated with standard verification statistics (available at www.nws.noaa.gov/ndfd/verification/) and has been formally evaluated in peer-reviewed studies (for example, Myrick and Horel, 2006).

As Glahn (2005) describes, to assess the skill and accuracy of the forecasts, they have to be matched with eventual reality. The USA-NPN is committed to evaluating the accuracy of gridded AGDD and SI-x forecast products constructed using NDFD data; plans for these assessments, including rolling forecast verification, are described in section 7.3.

The NWS provides ongoing verification of the NDFD short-term forecast products (www.nws.noaa.gov/ndfd/verification/); accordingly, we refer users to this resource for understanding uncertainty associated with these products. Likewise, NCEP provides ongoing verification for the RTMA products (www.emc.ncep.noaa.gov/mmb/rtma/para/00z/).

\subsection{Other Sources of Uncertainty}

With the Extended Spring Index products, parameter uncertainty adds potential error to these gridded products. The Spring Indices are models, or approximations of the real world, that are based on linear relationships between phenological events and meteorological variables (Ault, Zurita-Milla, and Schwartz, 2015). Because these models do not perfectly predict the timing of phenological events, a measure of uncertainty is introduced into the values reported through these gridded products.

The anomaly, or difference from average, products may incorporate an additional form of uncertainty because the methodology used in the generation of RTMA products is quantitatively different than that used in the creation of PRISM products. As the AGDD and SI-x anomaly 
products generated by the USA-NPN make use of both PRISM and RTMA data sources, errors may be introduced in the magnitude and pattern of the anomalies reported.

\subsection{Planned Activities for Estimating Uncertainty in USA-NPN Gridded Products}

The USA-NPN is exploring feasible and efficient ways to estimate uncertainty for each of the gridded products under production (table 2); these tools are implemented on a rolling basis as time allows for development.

Table 2. Planned activities for estimating uncertainty in USA-NPN gridded phenology products.

[Abbreviations used: NOAA, National Oceanic and Atmospheric Administration; NCEP, National Centers for Environmental Prediction; RTMA, Real-Time Mesoscale Analysis products; URMA, Unrestricted Mesoscale Analysis products; NWS, National Weather Service; NDFD, National Digital Forecast Database; PRISM, Parameter-elevation Relationships on Independent Slopes Model; AGDD, Accumulated Growing Degree Days; SI-x, Extended Spring Indices; CRN, Climate Reference Network]

\begin{tabular}{|c|c|c|c|}
\hline & $\begin{array}{c}\text { Temperature products (NOAA } \\
\text { NCEP RTMA and URMA, } \\
\text { NOAA NWS NDFD, PRISM) }\end{array}$ & AGDD products & SI-x products \\
\hline $\begin{array}{l}\text { Real-time } \\
\text { products }\end{array}$ & $\begin{array}{l}\text { See NOAA NCEP RTMA } \\
\text { verification at } \\
\text { http://www.emc.ncep.noaa } \\
\text {.gov/mmb/rtma/para/00z/ }\end{array}$ & $\begin{array}{l}\text { Compare NOAA NCEP RTMA- } \\
\text { based calculations to CRN-based } \\
\text { calculations }\end{array}$ & $\begin{array}{l}\text { Compare NOAA NCEP } \\
\text { RTMA-based calculations to } \\
\text { CRN-based calculations at } \\
\text { end of growing season; } \\
\text { compare RTMA-based } \\
\text { calculations to first leaf and } \\
\text { first flower dates reported } \\
\text { for lilacs via Nature's } \\
\text { Notebook (planned for fall } \\
\text { 2016) }\end{array}$ \\
\hline $\begin{array}{l}\text { Forecast } \\
\text { products }\end{array}$ & $\begin{array}{l}\text { See NOAA NWS NDFD } \\
\text { verification at } \\
\text { http://www.nws.noaa.gov/ } \\
\text { ndfd/verification/ }\end{array}$ & $\begin{array}{l}\text { Compare NDFD-based 6-day } \\
\text { forecast calculations to NOAA } \\
\text { NCEP URMA-based } \\
\text { calculations (not yet determined) }\end{array}$ & $\begin{array}{l}\text { Compare NDFD-based 6-day } \\
\text { forecast calculations to } \\
\text { NOAA NCEP URMA-based } \\
\text { calculations (not yet } \\
\text { determined) }\end{array}$ \\
\hline $\begin{array}{l}\text { Anomaly } \\
\text { products }\end{array}$ & Not applicable & $\begin{array}{l}\text { Compare NOAA NCEP URMA } \\
\text { and PRISM-based calculations } \\
\text { to station-based calculations } \\
\text { (under consideration) }\end{array}$ & $\begin{array}{l}\text { Compare NOAA NCEP } \\
\text { URMA and PRISM-based } \\
\text { calculations to station-based } \\
\text { calculations (under } \\
\text { consideration) }\end{array}$ \\
\hline $\begin{array}{l}\text { Historical } \\
\text { products }\end{array}$ & Not available for PRISM & Not applicable & $\begin{array}{l}\text { Compare PRISM-based } \\
\text { calculations to CRN-based } \\
\text { calculations at end of } \\
\text { growing season (planned for } \\
\text { spring 2017) }\end{array}$ \\
\hline
\end{tabular}

\subsubsection{Estimating Uncertainty in USA-NPN Real-Time Gridded Products}

One way to assess the accuracy in the RTMA and URMA-based AGDD grids being generated by the USA-NPN is to compare the values to an independent, reliable data source. The U.S. Climate Reference Network (CRN) was created to yield "an unimpeachable record of 
changes in surface climate over the United States," against which other data sets may be compared and validated (Diamond and others, 2013; Oswald and Dupigny-Giroux, 2015). Because the CRN station data are viewed as the "gold standard" for weather observations, we opted to use data from these stations for validating the RTMA and URMA gridded real-time temperature products. We access daily AGDD values at a number of geographically distributed CRN stations via the Applied Climate Information System (ACIS; www.rcc-acis.org/) and compare values for these locations to the AGDD values for the same locations as calculated by USA-NPN using the RTMA and URMA-based daily gridded products. These daily comparisons are available through a dashboard tool on the USA-NPN Web site (www.usanpn.org/agdd_uncertainty). These stations only capture a limited number of points across the continental United States but are geographically dispersed and represent diverse climatic regions. Monitoring differences between gridded product values at these station locations lends insight into the overall performance of the gridded products across the United States.

\subsubsection{Estimating Uncertainty in USA-NPN Real-Time SI-x Products}

As is done for the AGDD products, the day of year when the requirements for the Spring Indices were calculated to be met using RTMA and URMA gridded products will be compared to the day of year the requirements for the Spring Indices were calculated to be met at CRN stations. This comparison will be calculated once each year after day 240, after all locations across the United States would have met the Index requirements. These comparisons will be made available through a dashboard tool on the USA-NPN Web site. As with the AGDD comparison described in section 7.3.1, monitoring differences between gridded product values at these station locations will lend insight into the overall performance of the gridded products across the United States.

In another form of verification of the SI-x products, we will compare the timing of the first leaf and first bloom predicted by the models to observations of first leaf and first bloom reported via Nature's Notebook. This form of verification is imperfect because observer reports cannot be guaranteed as precise and accurate. Observers typically do not observe every day, leaving a window of time for when the date of first leaf or first bloom occurred between the day they first reported it and the last date a "no" observation was reported. Further, this form of verification only works for evaluating the performance of the individual species threshold models that comprise the Spring Indices, not for the Spring Indices themselves, which are a composite of three individual species models. Regardless, this form of verification will help us to identify regions where the SI-x modeled and reported values seem to be in close agreement or are dramatically different, and may direct future observer communications or recruitment activities.

We estimate these activities will be completed in fall 2016.

\subsubsection{Estimating Uncertainty in USA-NPN 1- to 6-Day Forecast AGDD Products}

As Glahn (2005) describes, to assess the skill and accuracy of forecasts, they have to be matched with eventual reality. In order to assess the accuracy of our AGDD 1- to 6-day forecasts, we plan to compare each NDFD-based AGDD 6-day forecast $(t+6)$ to the actual AGDD accumulation based on reported URMA values for that date, once URMA is considered finalized (at $\mathrm{t}-3$ ). This form of analysis will allow a user to evaluate the impact of the forecast 
accuracy on the accumulated temperature product. These results will be made available through a tool on the USA-NPN Web site.

A timeframe for these activities has not yet been established.

\subsubsection{Estimating Uncertainty in USA-NPN 1- to 6-Day Forecast SI-x Products}

The Spring Index gridded layers differ from the AGDD gridded layers in that the pixel values represent the day of year that the requirements for the index were met, rather than a sum of accumulated growing degree days. Accordingly, from one day to the next, the majority of the pixels comprising the Spring Index maps do not change. To evaluate Spring Index forecast products similar to the AGDD forecast products described immediately above, the day of year predicted for the Spring Index to be met for the group of pixels predicted to change in the coming 1 to 6 days would need to be compared to the day of year actually reported for the Spring Index. This form of analysis would allow a user to evaluate the impact of the forecast accuracy on the accumulated temperature product. These results will be made available through a tool on the USA-NPN Web site. A timeframe for these activities has not yet been established.

\subsubsection{Estimating Uncertainty in USA-NPN Anomaly AGDD Products}

One way to estimate error in AGDD anomaly products produced by the USA-NPN would be to compare values calculated on a particular day using the RTMA and URMA contemporary products and PRISM 30-year average product to long-term average AGDD calculations for the same day of year made at reliable weather stations. Most CRN stations have a record shorter than 30 years, so in order for the period of record used in calculating the long-term average at the stations to be comparable to the 30-year average calculated using PRISM gridded temperature data, we would need to draw upon another set of reliable weather stations. The feasibility and efficiency of undertaking this form of uncertainty estimation is currently being explored by the USA-NPN gridded products development team.

A timeframe for these activities has not yet been established.

\subsubsection{Estimating Uncertainty in USA-NPN Anomaly SI-x Products}

One way to estimate error in SI-x anomaly products produced by the USA-NPN would be to compare values calculated on a particular day using the RTMA and URMA contemporary products and PRISM 30-year average product to long-term average SI-x calculations for the same day of year made at reliable weather stations. Most CRN stations have a record shorter than 30 years, so in order for the period of record used in calculating the long-term average at the stations to be comparable to the 30-year average calculated using PRISM gridded temperature data, we would need to draw upon another set of reliable weather stations. The feasibility and efficiency of undertaking this form of uncertainty estimation is currently being explored by the USA-NPN gridded products development team.

A timeframe for these activities has not yet been established.

\subsubsection{Estimating Uncertainty in USA-NPN Historical Data Products}

For each of the historical SI-x Leaf Index and Bloom Index layers (1981-2015), the day of year when the requirements for the Spring Indices were calculated to be met using PRISM gridded products will be compared to the day of year the requirements for the Spring Indices 
were calculated to be met at $\mathrm{CRN}$ stations. These comparisons will be made available through a dashboard tool on the USA-NPN Web site.

We estimate these activities will be completed in spring 2017. 


\section{References Cited}

Abrams, Elliot, 2004, Implementation and refinement of digital forecasting databases: Bulletin of the American Meteorological Society, v. 85, no. 11, p. 1667-1672. [Also available at http://dx.doi.org/10.1175/BAMS-85-11-1667.]

Allstadt, A.J., Vavrus, S.J., Heglund, P.J., Pidgeon, A.M., Thogmartin, W.E., and Radeloff, V.C., 2015, Spring plant phenology and false springs in the conterminous US during the $21 \mathrm{st}$ century: Environmental Research Letters, v. 10, no. 10, letter 104008, 24 p., accessed October 14, 2015, at http://dx.doi.org/10.1088/1748-9326/10/10/104008.

Ault, T.R., Schwartz, M.D., Zurita-Milla, Raul, Weltzin, J.F., and Betancourt, J.L., 2015, Trends and natural variability of spring onset in the coterminous United States as evaluated by a new gridded dataset of spring indices: Journal of Climate, v. 28, no. 21, p. 8363-8378, accessed February 28, 2016, at http://dx.doi.org/10.1175/JCLI-D-14-00736.1.

Ault, T.R., Zurita-Milla, Raul, and Schwartz, M.D., 2015, A Matlab® toolbox for calculating spring indices from daily meteorological data: Computers \& Geosciences, v. 83, p. 46-53, accessed November 15, 2016, at http://dx.doi.org/10.1016/j.cageo.2015.06.015.

Behnke, R., Vavrus, S., Allstadt, A., Albright, T., Thogmartin, W.E., and Radeloff, V.C., 2016, Evaluation of downscaled, gridded climate data for the conterminous United States: Ecological Applications, v. 26, no. 5, p. 1338-1351, accessed February 15, 2016, at http://dx.doi.org/10.1002/15-1061.

Bishop, D.A., and Beier, C.M., 2013, Assessing uncertainty in high-resolution spatial climate data across the US Northeast: PLoS ONE, v. 8, no. 8, article e70260, 15 p., accessed February 9, 2016, at http://dx.doi.org/10.1371/journal.pone.0070260.

Cross, H.Z., and Zuber, M.S., 1972, Prediction of flowering dates in maize based on different methods of estimating thermal units: Agronomy Journal, v. 64, no. 3, p. 351-355, accessed February 8, 2016, at http://dx.doi.org/10.2134/agronj1972.00021962006400030029x.

Daly, Christopher, 2006, Guidelines for assessing the suitability of spatial climate data sets: International Journal of Climatology, v. 26, no. 6, p. 707-721, accessed February 9, 2016, at http://dx.doi.org/10.1002/joc.1322.

Daly, Christopher, Gibson, W.P., Taylor, G.H., Johnson, G.L., and Pasteris, Phillip, 2002, A knowledge-based approach to the statistical mapping of climate: Climate Research, v. 22, no. 2, p. 99-113, accessed February 9, 2016, at http://dx.doi.org/10.3354/cr022099.

Daly, Christopher, Halbleib, Michael, Smith, J.I., Gibson, W.P., Doggett, M.K., Taylor, G.H., Curtis, Jan, and Pasteris, P.P., 2008, Physiographically sensitive mapping of climatological temperature and precipitation across the conterminous United States: International Journal of Climatology, v. 28, no. 15, p. 2031-2064, accessed February 9, 2016, at http://dx.doi.org/10.1002/joc.1688. 
Daly, Christopher, Neilson, R.P., and Phillips, D.L., 1994, A statistical-topographic model for mapping climatological precipitation over mountainous terrain: Journal of Applied Meteorology, v. 33, no. 2, p. 140-158, accessed February 9, 2016, at http://dx.doi.org/10.1175/1520-0450(1994)033<0140:ASTMFM>2.0.CO;2.

Diamond, H.J., Karl, T.R., Palecki, M.A., Baker, C.B., Bell, J.E., Leeper, R.D., Easterling, D.R., Lawrimore, J.H., Meyers, T.P., Helfert, M.R., Goodge, Grant, and Thorne, P.W., 2013, U.S. Climate Reference Network after one decade of operations: Bulletin of the American Meteorological Society, v. 94, no. 4, p. 485-498, accessed February 12, 2016, at http://dx.doi.org/10.1175/BAMS-D-12-00170.1.

de Pondeca, M.S.F.V., Manikin, G.S., DiMego, Geoff, Benjamin, S.G., Parrish, D.F., Purser, R.J., Wu, W.-S., Horel, J.D., Myrick, D.T., Lin, Ying, Aune, R.M., Keyser, Dennis, Colman, Brad, Mann, Greg, and Vavra, Jamie, 2011, The Real-Time Mesoscale Analysis at NOAA's National Centers for Environmental Prediction; Current status and development: Weather and Forecasting, v. 26, no. 5, p. 593-612, accessed February 9, 2016, at http://dx.doi.org/10.1175/WAF-D-10-05037.1.

Gerst, K.A., Rosemartin, A.H., Denny, E.G., Enquist, C.A.F., Marsh, R.L., Moore, D.J.P., Crimmins, T.M., and Weltzin, J.F., 2015, USA National Phenology Network data product development framework and data product catalog, ver. 1.0: USA-NPN Technical Series 2015001, 24 p., accessed April 2, 2015, at https://www.usanpn.org/pubs/reports.

Glahn, Bob, 2005, Comments on "Implementation and refinement of digital forecasting databases": Bulletin of the American Meteorological Society, v. 86, no. 9, p. 1315-1318. [Also available at http://dx.doi.org/10.1175/BAMS-86-9-1315.]

Glahn, H.R., and Ruth, D.P., 2003, The digital forecast database of the National Weather Service: Bulletin of the American Meteorological Society, v. 84, no. 2, p. 195-201. [Also available at http://dx.doi.org/10.1175/BAMS-84-2-195.]

McMaster, G.S., and Wilhelm, W.W., 1997, Growing degree-days; One equation, two interpretations: Agricultural and Forest Meteorology, v. 87, no. 4, p. 291-300. [Also available at http://dx.doi.org/10.1016/S0168-1923(97)00027-0.]

Myrick, D.T., and Horel, J.D., 2006, Verification of surface temperature forecasts from the National Digital Forecast Database over the Western United States: Weather and Forecasting, v. 21, no. 5, p. 869-892, accessed February 9, 2016, at http://dx.doi.org/10.1175/WAF946.1.

Oswald, E.M., and Dupigny-Giroux, L.-A., 2015, On the availability of high-resolution data for near-surface climate analysis in the continental U.S.: Geography Compass, v. 9, no. 12, p. 617-636, accessed February 9, 2016, at http://dx.doi.org/10.1111/gec3.12249.

Pielke, R.A., Sr., Stohlgren, T., Schell, L., Parton, W., Doesken, N., Redmond, K., Moeny, J., McKee, T., and Kittel, T.G.F., 2002, Problems in evaluating regional and local trends in temperature; An example from eastern Colorado, USA: International Journal of Climatology, v. 22, no. 4, p. 421-434, accessed February 12, 2016, at http://dx.doi.org/10.1002/joc.706. 
Schwartz, M.D., 1992, Phenology and springtime surface-layer change: Monthly Weather Review, v. 120, no. 11, p. 2570-2578. [Also available at http://dx.doi.org/10.1175/15200493(1992)120<2570:PASSLC >2.0.CO;2.]

Schwartz, M.D., 1997, Spring index models; An approach to connecting satellite and surface phenology, in Lieth, H., and Schwartz, M.D., eds., Phenology in Seasonal Climates I: Leiden, The Netherlands, Backhuys Publishers, p. 23-38.

Schwartz, M.D., Ahas, Rein, and Aasa, Anto, 2006, Onset of spring starting earlier across the Northern Hemisphere: Global Change Biology, v. 12, no. 2, p. 343-351. [Also available at http://dx.doi.org/10.1111/j.1365-2486.2005.01097.x.]

Schwartz, M.D., Ault, T.R., and Betancourt, J.L., 2013, Spring onset variations and trends in the continental United States; Past and regional assessment using temperature-based indices: International Journal of Climatology, v. 33, no. 13, p. 2917-2922, accessed September 15, 2015, at http://dx.doi.org/10.1002/joc.3625.

Slingo, Julia, and Palmer, Tim, 2011, Uncertainty in weather and climate prediction: Philosophical Transactions of the Royal Society A, v. 369, no. 1956, p. 4751-4767, accessed February 9, 2016, at http://dx.doi.org/10.1098/rsta.2011.0161.

USA-NPN National Coordinating Office, 2014, USA National Phenology Network five-year strategic plan (FY14-FY18): USA-NPN Programmatic Series 2014-001, 26 p., accessed September 1, 2016, at https://www.usanpn.org/pubs/reports.

U.S. Census Bureau, Geography Division, 2015, Cartographic boundary shapefiles - States [2015]: U.S. Census Bureau data, accessed February 8, 2016, at https://www.census.gov/geo/maps-data/data/cbf/cbf_state.html 


\section{Appendix. USA-NPN Geoserver Documentation}

\section{Introduction}

This document provides information about how to access the contents of the Geoserver instance hosted by the USA-NPN. This document is available online at docs.google.com/document/d/1jDqeh8k30t0vEBAJu2ODiipaofLZ2PFgsaNzhhzz3xg/pub.

\section{Geoserver Location}

The USA-NPN Geoserver is located at geoserver.usanpn.org/geoserver/. This link can be built upon in various ways to make requests to the Geoserver, as described in the sections below.

\section{Geoserver Hierarchy}

Geoserver has workspaces that contain layers. Currently the USA-NPN Geoserver has three workspaces: climate, gdd, and si-x. The layers contained in each workspace are listed below.

1. climate

- $\operatorname{tmin}$

- tmax

2. gdd

- agdd

- 30yr_avg_agdd

- agdd_anomaly

- agdd_50f

- 30yr_avg_agdd_50f

- agdd_anomaly_50f

3. si-x

- lilac_leaf_prism

- arnoldred_leaf_prism

- zabellii_leaf_prism

- average_leaf_prism

- lilac_bloom_prism

- arnoldred_bloom_prism

- zabelli_bloom_prism

- average_bloom_prism

- lilac_leaf_ncep

- arnoldred_leaf_ncep

- zabelli_leaf_ncep

- average_leaf_ncep

- lilac_bloom_ncep

- arnoldred_bloom_ncep

- zabelli_bloom_ncep

- average_bloom_ncep 
- 30yr_avg_six_leaf

- 30yr_avg_six_bloom

- leaf_anomaly

- bloom_anomaly

\section{Geoserver Web Services}

Web Coverage Service (WCS; www.opengeospatial.org/standards/wcs) and Web Mapping Service (WMS; www.opengeospatial.org/standards/wms) are two OGC (Open Geospatial Consortium) Web service standards that the USA-NPN Geoserver instance exposes. Each layer can be accessed via either service. The WMS service can deliver raster images of various types including JPEGs, animated GIFs, GeoTIFFs, and openlayers. When something more than a simple image is required, WCS should be used (for example, when the underlying raster data will be used in geospatial analysis). WCS also has the advantage of being able retrieve a subset of the geospatial data based on minimum and maximum latitudes and longitudes. Formats available from each service are listed below:

1. WCS

- application/gml+xml

- application/gtopo30

- application/x-gzip

- application/x-netcdf

- image/jpeg

- image/png

- image/tiff

- text/plain

- image/geotiff

2. WMS

- image/png

- application/atom+xml

- application/pdf

- application/rss $+x m l$

- application/vnd.google-earth.kml+xml

- application/vnd.google-earth.kml+xml;mode=networklink

- application/vnd.google-earth.kmz

- image/geotiff

- image/geotiff8

- image/gif

- image/jpeg

- image/png; mode $=8$ bit

- image/svg+xml

- image/tiff

- image/tiff8

- text $/ \mathrm{html} ;$ subtype $=$ openlayers 


\section{Discovering Geoserver Services Through GetCapabilities}

Each Web service can be explored through a GetCapabilities request. The request will return information about what the Web service provides, in XML format. For instance, GetCapabilities shows each workspace, layer, available file type, available time, an abstract of each layer, and much more. GetCapabilities requests for each Web service are as follows: WMS (geoserver.usanpn.org/geoserver/ows? service=wms\&version=1.3.0\&request $=$ GetCapabilities) and WCS

(geoserver.usanpn.org/geoserver/ows?service=WCS\&version=2.0.1\&request=GetCapabilities).

\section{Discovering Web Coverage Service (WCS) Through DescribeCoverage}

In addition to GetCapabilities, WCS has another request called DescribeCoverage. This request retrieves an XML document that fully describes the requested coverage in more detail than GetCapabilities. The following example shows how to get a description of the agdd_50f coverage from the gdd workspace:

geoserver.usanpn.org/geoserver/ows? service $=$ WCS\&version=2.0.1\&request $=$ DescribeCoverage \&coverageID=gdd:agdd_50f.

\section{Temporal Layers}

Most layers have a temporal aspect to them. Currently there are three different types of time intervals:

- Daily (one grid per calendar date)

- Yearly (one grid per year)

- Day of year (one grid per day of year)

Specifying temporal parameters works differently for WCS and WMS. The following are examples for specifying January, 7, 2016, as the date or day of year, or 2016 for the year. The "Temporal resolution" and "Temporal range available" descriptors provided above for each layer provide users with the information to specify the proper form of time interval. This information is also available in the GetCapabilities.

1. WCS

- Daily is specified as

\&subset=http://www.opengis.net/def/axis/OGC/0/time("2016-0107T00:00:00.000Z")

- Yearly is specified using the first day of the year \&subset=http://www.opengis.net/def/axis/OGC/0/time("2016-0101T00:00:00.000Z")

- Day of year is specified as \&subset=http://www.opengis.net/def/axis/OGC/0/elevation(07)

2. WMS

- Daily is specified as $\mathbf{\&}$ time $=\mathbf{2 0 1 6 - 1 - 7}$

- Yearly is specified as \&time=2016

- Day of year is specified as \&elevation=7

Geoserver is queried for different days of year using a parameter called elevation. At the current time, Geoserver only supports time and elevation parameters. If you want to query on 
numbers in the range of 1-365 you have to use elevation. Hopefully this will change in the future.

\section{Building a Web Coverage Service (WCS) Request}

A step by step example to building up a WCS request is outlined here. At each step except the first, the parameter is appended onto the right of the base URL. Note that until step 9 the URL is incomplete and won't function.

1. Start with the base link: geoserver.usanpn.org/geoserver/

2. Specify the workspace: geoserver.usanpn.org/geoserver/climate

3. Specify the Web service as WCS: geoserver.usanpn.org/geoserver/climate/wcs?service=WCS

4. Specify the version: geoserver.usanpn.org/geoserver/climate/wcs?service $=$ WCS\&version=2.0.1

5. Specify the request as GetCovereage: geoserver.usanpn.org/geoserver/climate/wcs? service $=$ WCS\&version $=2.0 .1$ \& request $=$ GetCoverage

6. Specfiy the coverage ID: geoserver.usanpn.org/geoserver/climate/wcs? service $=$ WCS\&version $=2.0 .1 \&$ request $=$ Get Coverage \& CoverageId=climate:tmin

7. Specify the spatial reference system (most layers default to EPSG:4269, which corresponds to North American Datum 1983): geoserver.usanpn.org/geoserver/climate/wcs? service $=$ WCS\&version $=2.0 .1 \&$ request $=$ Get Coverage \&CoverageId=climate:tmin\&srs=EPSG:4269

8. Specify a date: geoserver.usanpn.org/geoserver/climate/wcs?service=WCS\&version=2.0.1\&request $=$ Get Coverage\&CoverageId=climate:tmin\&srs=EPSG:4269\&subset=http://www.opengis. net/def/axis/OGC/0/time("2016-01-14T00:00:00.000Z")

9. Specify the format: geoserver.usanpn.org/geoserver/climate/wcs? service=WCS\&version=2.0.1\&request $=$ Get Coverage\&CoverageId=climate:tmin\&srs=EPSG:4269\&subset=http:/www.opengis.net/ def/axis/OGC/0/time("2016-01-14T00:00:00.000Z")\&format=image/geotiff

\section{Building a Web Mapping Service (WMS) Request}

A step by step example to building up a WMS request is outlined here. At each step except the first, the parameter is appended onto the right of the base URL. Note that until step 11 the URL is incomplete and won't function. Also, following step 4, parameters can be appended in any order.

1. Start with the base URL: geoserver.usanpn.org/geoserver/

2. Specify the workspace: geoserver.usanpn.org/geoserver/climate

3. Specify the Web service as wms: http://geoserver.usanpn.org/geoserver/climate/wms/ 
4. Specify the request as GetMap:

geoserver.usanpn.org/geoserver/climate/wms/?request=GetMap

5. Specify the layer:

geoserver.usanpn.org/geoserver/climate/wms/?request=GetMap\&layers=climate:tmin

6. Specify the bounding box as two latitude and longitude coordinates, in decimal degrees: geoserver.usanpn.org/geoserver/climate/wms/?request $=$ GetMap\&layers $=$ climate:tmin \&b box $=-125.020833333333,24.0625,-66.479166666662,49.937500000002$

7. Specify the width and height (in pixels):

geoserver.usanpn.org/geoserver/climate/wms/?request=GetMap\&layers $=$ climate:tmin \&b box $=-125.020833333333,24.0625,-$ $66.479166666662,49.937500000002$ \&width $=\mathbf{1 6 0 0}$ \&height $=\mathbf{6 0 0}$

8. Specify the spatial reference system (most layers default to EPSG:4269, which corresponds to North American Datum 1983):

geoserver.usanpn.org/geoserver/climate/wms/?request=GetMap\&layers $=$ climate:tmin\&b box $=-125.020833333333,24.0625,-$

66.479166666662,49.937500000002\&width $=1600 \&$ height $=600 \&$ srs $=$ EPSG:4269

9. If you want a specific layout for added text or color ramp specify the format options:

geoserver.usanpn.org/geoserver/climate/wms/?request $=$ GetMap\&layers $=$ climate:tmin\&b box $=-125.020833333333,24.0625,-$

$66.479166666662,49.937500000002 \&$ width $=1600 \&$ height $=600 \&$ srs $=$ EPSG:4269\&form at_options=layout:leaf

10. Specify a date:

geoserver.usanpn.org/geoserver/climate/wms/?request $=$ GetMap\&layers $=$ climate:tmin $\& b$ box $=-125.020833333333,24.0625,-$

66.479166666662,49.937500000002\&width=1600\&height $=600 \&$ srs $=$ EPSG:4269\&form at_options=layout:leaf\&time $=\mathbf{2 0 1 6 - 1 - 1 4}$

11. Specify the format:

geoserver.usanpn.org/geoserver/climate/wms/?request=GetMap\&layers $=$ climate:tmin \&b box $=-125.020833333333,24.0625,-$

66.479166666662,49.937500000002\&width $=1500 \&$ height $=600 \&$ srs $=$ EPSG:4269\&form

at_options=layout:leaf\&time=2016-1-14\&format=openlayers\#toggle

Animated GIF from a Layer

The time and elevation parameters in a WMS request can be given a sequence of values and Geoserver will return an animated GIF. To do this, use the following:

\&format=image/gif;subtype=animated\&aparam=time\&avalues=val1,val2,val3,... Here are a few examples:

1. lilac, first leaf, years 1981 through 2015 (without specifying width and height or requesting color ramp)

geoserver.usanpn.org/geoserver/si-x/wms/animate?layers=si-

x:lilac_leaf_prism\&format=image/gif;subtype $=$ animated\&aparam $=$ time $\&$ avalues $=1981,1$ 982,1983,1984,1985,1986,1987,1988,1989,1990,1991,1992,1993,1994,1995,1996,1997,1 998,1999,2000,2001,2002,2003,2004,2005,2006,2007,2008,2009,2010,2011,2012,2013,2 014,2015\&format_options=layout:animation\&bbox=-125.020833333333,24.0625,$66.479166666662,49.937500000002$ 
2. lilac, first leaf, years 1981 through 2015 (specifying width, height, and layout to get color ramp)

geoserver.usanpn.org/geoserver/si-x/wms/animate?layers=si-

x:lilac_leaf_prism\&format $=$ image/gif;subtype $=$ animated\&aparam $=$ time\&avalues $=1981,1$

982,1983,1984,1985,1986,1987,1988,1989,1990,1991,1992,1993,1994,1995,1996,1997,1

998,1999,2000,2001,2002,2003,2004,2005,2006,2007,2008,2009,2010,2011,2012,2013,2

014,2015\&format_options=layout:leaf\&bbox $=-125.020833333333,24.0625,-$

$66.479166666662,49.937500000002$ \&width $=1200$ \&height $=600$

3. lilac, first leaf, current year bimonthly (1st and 15th of January through June 2016)

geoserver.usanpn.org/geoserver/si-x/wms/animate?layers=si-

x:lilac_leaf_ncep\&styles $=$ si-

$\mathrm{x}$ :leafout bimonthly_web,\&format=image/gif;subtype=animated\&aparam=time\&avalues

$=2016-01-01,2016-01-15,2016-02-01,2016-02-15,2016-03-01,2016-03-15,2016-04-$

01,2016-04-15,2016-05-01,2016-05-15,2016-06-01,2016-06-

15\&format_options=layout:leaf\&bbox $=-125.020833333333,24.0625,-$

$66.479166666662,49.937500000002 \&$ width $=1800$ \&height $=800$

To ensure that the color ramp doesn't overlap the map area in the animation,

add \&styles=leafout_bimonthly_web to the end of the link:

geoserver.usanpn.org/geoserver/si-x/wms/animate?layers=si-

x:lilac_leaf_prism\&format=image/gif;subtype $=$ animated\&aparam $=$ time\&avalues $=1981,1982,19$

$83,1984,1985,1986,1987,1988,1989,1990,1991,1992,1993,1994,1995,1996,1997,1998,1999,200$

$0,2001,2002,2003,2004,2005,2006,2007,2008,2009,2010,2011,2012,2013,2014,2015 \&$ format_o ptions=layout:leaf\&bbox $=-125.020833333333,24.0625,-$

$66.479166666662,49.937500000002 \&$ width $=1200 \&$ height=600\&styles=leafout_bimonthly_web

\section{Retrieving a Color Ramp with GetLegendGraphic}

A stand-alone color ramp can be retrieved for any WMS layer with the

GetLegendGraphic request. This is ideal because each map and color ramp can be retrieved independently at different sizes for presentation. The color ramp can be resized with the width and height parameters and is available in a variety of image formats (the same formats available to the WMS GetMap request). The following example retrieves the default color ramp for the Tmin layer in the climate workspace as a 20 - by 40 -pixel PNG image:

geoserver.usanpn.org/geoserver/wms?REQUEST $=$ GetLegendGraphic\&VERSION=1.3.0 $\&$ FORMAT=image/png\&WIDTH=20\&HEIGHT=40\&LAYER=climate $:$ tmin .

\section{WMS Layouts}

The purpose of a layout is to combine and position other elements such as a color ramp, supplemental text, title, or logo relative to a requested map. Each layout has to be created in advance. Each GetMap request can be supplemented with a layout by using the parameter \&format_options=layout:layoutname, where the layoutname is one of the following currently available layouts: leaf, bloom, leaf_animation, bloom_animation, and agdd_animation. Most of the current layouts display a color ramp on the right and, for animations, display date text in the bottom left corner. The following request retrieves a spring index leaf out JPEG using the leaf layout for February 1, 2016: 
geoserver.usanpn.org/geoserver/si-x/wms?service=WMS\&request=GetMap\&layers=six:lilac_leaf_ncep\&time=2016-2-1\&format_options=layout:leaf\&styles=\&bbox $=-$ $125.020833333333,24.0625,-$ 66.479166666662,49.937500000002\&width=1000\&height=600\&srs=EPSG:4269\&format=imag e/jpeg.

\section{Displaying State Boundaries Through WMS}

Each workspace has a States layer containing U.S. State boundaries. Any WMS layer can be viewed with an overlay of U.S. State boundaries. To view State boundaries append ,worskpace:states to the end of the layers attribute. For example, \&layers=climate:tmin becomes \&layers=climate:tmin,climate:states in the WMS request. The following example is a complete request with State boundaries:

geoserver.usanpn.org/geoserver/climate/wms? service=WMS\&request $=$ GetMap\&layers $=$ climate:tmin,climate:states\&time=2016-1-14\&format_options=layout:leaf\&styles=\&bbox=$125.020833333333,24.0625,-$ 66.479166666662,49.937500000002\&width $=1500 \&$ height $=600 \&$ srs $=$ EPSG:4269\&format $=$ open layers\#toggle. 
ISSN 2331-1258 (online)

https://doi.org/10.3133/ofr20171003 